\title{
Post-Reformation Reformed exegesis: Continuity or discontinuity of John Calvin?
}

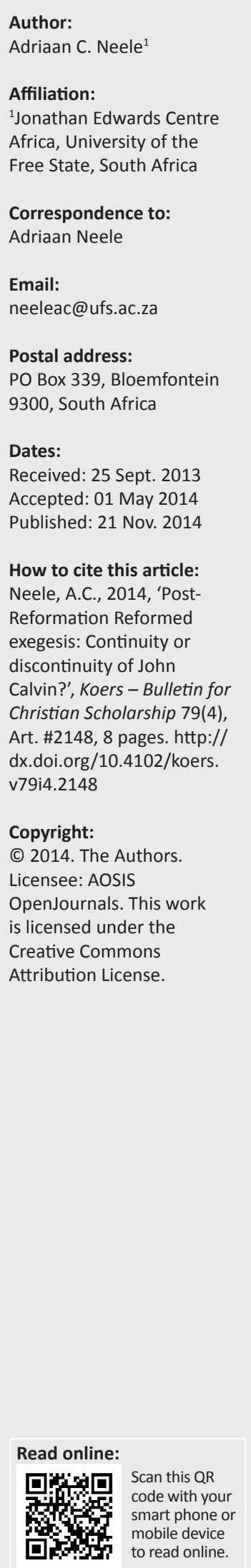

Although the Post-Reformation Reformed theologian, philosopher and Hebraist Petrus van Mastricht (1630-1706) praises John Calvin (1509-1564) as one of the best commentators of Scripture, he rarely refers to Calvin's work in his Theoretico-practica theologia and, if he does, he either takes issue or concurs with it. This contribution explores the reception of Calvin's work by Mastricht, focusing on exegetical continuities and discontinuities in their comments on the psalms. It concludes that Mastricht gives more attention to etymological and philological issues of the Hebrew text than Calvin does, and emphasises more than the Genevan Scripture commentator does the doctrine of divine immensity and the Reformed concept of the covenant.

Na-Reformatoriese gereformeerde eksegese: Kontinuïteit of diskontinuïniteit van Johannes Calvyn? Hoewel die na-Reformatoriese gereformeerde teoloog, filosoof en Hebraïs, Petrus van Mastricht (1630-1706), Johannes Calvyn (1509-1564) as een van die beste eksegete van die Skrif prys, het hy in sy Theoretico-praktica theologia selde na Calvyn se werk verwys. Wanneer dit wel die geval was, het hy daarvan verskil of krities daarmee saamgestem. Hierdie bydrae verken die hantering van Calvyn se werk deur Mastricht, deur op eksegetiese kontinuiteit en diskontinuïteit in hul onderskeie kommentare op die Psalms te fokus. Dit kom tot die gevolgtrekking dat Mastricht meer aandag aan etimologiese en filologiese kwessies van die Hebreeuse teks gee as Calvyn, en ook meer as die Geneefse Bybel kommentator die leer van die Goddelike grootsheid en die Gereformeerde verbondsbeskouing beklemtoon.

\section{Introduction}

Since it has so often been implied that the Reformation was a time of exegesis, virtually without dogma, and the era of orthodoxy was a time of dogmatic system without exegesis, it must be added that at no time before or since the era of orthodoxy was systematic theology so closely wedded to the textual and linguistic work of the exegete.

In this regard, Richard A. Muller (2007:31) in the Dictionary of major biblical interpreters, expertly provides an overview of Scripture commentators of the Reformation and Post-Reformation era, including but not limited to issues of exegetical continuity and discontinuity. Although the number of Post-Reformation studies in general and of John Calvin (1509-1563) studies in particular continue to offer new insights, ${ }^{1}$ the attention to biblical exegesis in these fields of research differs in various ways. Firstly, though the studies of Calvin and exegesis remain of interest, (see for example: Berthoud 2010:105-22; Cobb 2010:21-36; d'Assonville 2009:378-384, 2010; Engammare 2012:53-72; Handy 2009:79-89; Holdt 2010:215-224; Nicole 2010:1-20; Wilcox 2011:125-30) - the examination of the method and practice of biblical interpretation of PostReformation documents awaits a much-needed appraisal. ${ }^{2}$ Furthermore, as I have suggested elsewhere, the exegetical reflections of the 17th century Reformed theology, in particular, are appraised in one of two ways: either orthodox doctrinal impositions disordered the biblical exegesis, separating praxis from exegesis, or the exegesis of Scripture was directive and determinative for doctrinal and practical theological reflections (Neele 2009). Secondly, though hinted at by Muller (2007:35) the attention to the reception of the exegetical work of Calvin in Post-Reformation works is often overlooked. ${ }^{3}$ Two possible reasons for this lack of concern can be mention here: the exegetes and theologians of the Post-Reformation Reformed era, in particular, were hindered by the established doctrine and confessions since the Synod of Dordrecht

1.On Calvin studies see for example, H. Henry Meeter Center (n.d.) and on Post-Reformation studies see Post Reformation Digital Library (n.d.).

2.This observation is underscored by (1) the lack of attention given to Post-Reformation biblical interpretation in studies such as Bray (1996); (2) the deficiency of studies of exegesis in the Nadere Reformatie, even while one notices an increase and diversification of studies of this period (cf. Huisman 2001), and (3) 'A full history of biblical interpretation in the 16th century and 17th century remains to be written' (Muller 2007:23)

3.Notable exceptions are: Muller (2009:211-225); Van Asselt (2011:135-147) 
1618-1619 and, therefore, Calvin's commentaries on Scripture were not consulted. ${ }^{4}$ In contrast, the 17 th century Reformed orthodoxy was so deeply acquainted with Calvin's thought that no specific reference was required. This thought is elaborated by Matthew Poole (1624-1679) - a Bible commentator par excellence, providing specific reasons of the exclusion or limited use of the Genevan Scripture commentator. Calvin's work, Poole asserted, was more a theological and practical than a critically oriented commentary, in particular related to etymology. Furthermore, Poole continued, Calvin's commentary was widely used in other commentaries on Scripture and was consulted by many. ${ }^{5}$ Here, Poole may have represented the thought of many of the Post-Reformation era: Calvin was not unknown, but was not often mentioned in the works of such commentators as Johannes Cocceius (1603-1669) and Campegius Vitringa (1659-1722), or of theologians such as Francis Turretin (1623-1687). Therefore, when Calvin is cited in Post-Reformation works, one must pay attention to such references. ${ }^{6}$

Illustrative of this is the Theoretico-practica theologia (hereafter TPT) of Petrus van Mastricht (1630-1706) (see Van Mastricht 1699). Mastricht commends Calvin as one of the best commentators of Scripture for exegesis ${ }^{7}$ and refers in the TPT to the Scripture exposition of the preacher and teacher of Geneva, Mastricht seems either to concur or to conflict with Calvin's exposition. This article therefore seeks to explore the reception or appropriation of Calvin's work by Mastricht and aims in particular to clarify exegetical continuities and discontinuities, and the relationship between exegesis, doctrine and praxis, if any.

To that purpose I will, first, provide a general overview of the use of Calvin's work in Mastricht's TPT; second, and in particular, I will offer a comparative analysis of some of Calvin's and Mastricht's exegetical insights; and, finally, I will end with some concluding remarks.

\section{Mastricht's use of Calvin's work}

Mastricht's TPT was the result of a 33-year project of theological reflection, commenced at Glückstadt in 1666 and

4.According to Berkhof (1950:29), 'exegesis became the handmaid of dogmatics and degenerated into a mere search of proof-texts'. Further, as stated by O'Dell Bullock (2002:129), 'the [post-reformation] Scholastics often superimposed their own sets of rationalistic guidelines upon its [the text of Holy Writ] pages, with the result that the simple message was often lost in the search for methodological and doctrinal correctness'; Graafland (1993:35) states: 'We krijgen niet zelden de indruk, dat de leer al lang vastaat, en dat ze alleen nog maar achteraf uit de Schrift moet worden bevestigd. Dat secundaire karakter van het Schrifbewijs is bij Voetius opvallend' Greijdanus (1946) argued that the development of exegesis in the period 1600Greijdanus (1946) argued that the development of exegesis in the perio
1750 was further hindered by the strong adherence to the confessions.

5.According to Poole (1669-1676), 'Mirentur forsan nonnulli, in Auctorum catalogo non comparere Joannem Calvinum, Interpretem 1. Ex eo nonnulla, ubi opus suerat, subindè delibavi 2.Calvini Commentaria non tam Critici sunt quàm materias Theologicas solidè tractant, \& ad praxin accommodant. 3. Ex Calvino pleraque decerpserunt qui post eum scripserunt 4.Calvinum sere omnes in minibus \& bibliothecis habent ....

6.This is especially applicable when Calvin's work is referenced in 17th century academic works. Academic works arising from university lectures and disputations of the early modern era, in general, identified used sources and authors. See, for of the early modern era, in general, identified used sources and authors. See, for
example, Cloppenburg (1684); Coccejus (1665); Hoornbeek (1689); Burmannus (1671); Cocceius (1701); Heidanus (1686); Heidegger (1700).

7.Mastricht 8: 'Exegeseos adminicula repetantur ... Commentatoribus praestantissimis, cum criticis \& verbalibus; tum analyticis ac realibus, Calvino, Piscatore, Polo \&c.' completed at Utrecht in 1699 - a culmination of disputations, treatises and other publications. Mastricht, professor of the Hebrew language, philosophy and practical theology, unfolded the enterprise of theology with a fourfold approach: exegesis, doctrine, elenctics and praxis. As such, his work is appraised as a codification of 17th century Reformed Orthodoxy. ${ }^{8}$ Mastricht cites no less than 150 authors and their works in it, showing for the most part a continuity of the catholicity of Christian theology throughout the ages, including the patristic fathers, medieval sources, and past and present Lutheran and Reformed theologians. In the exegetical parts he frequently resorts to rabbinical commentaries; in the doctrinal sections, primarily to the works of Augustine (for example, Mastricht $1699^{\circ}$ ); in the elenctic sections, to his own work Novitatum cartesianarum gangræna refuting Cartesian thought ${ }^{10}$; and in the practical sections, predominantly the works of Bernard of Clairvaux. ${ }^{11}$

Remarkably, among this vast number of references and citations throughout the TPT, the person and works of Calvin are rarely mentioned - that is to say, in a work of 1300 pages with double columns, Calvin's name comes up only 22 times, and only in the discussions of the following loci: prolegomena (4x), God (7x), Christ (7x), and the church (4x). ${ }^{12}$ Furthermore, the majority of these references to Calvin and his work are found in the doctrinal and elenctic sections of such loci though primarily mentioned in concert with other Protestant reformers. ${ }^{13}$ For example, in the prolegomena on the nature of theology, he argues in favour of a systematic approach of the method of theology as found, according to Mastricht, in the works of Zwingli, Luther, Melanchthon, Calvin, Bullinger, Musculus, Martyr, Ursinus and Zanchius. Furthermore, to cite another example, Mastricht refers to Calvin approvingly in his discussion on the historical development and doctrinal formulation of the Trinity, albeit indirectly and through Calvin's debate with the anti-Trinitarians. ${ }^{14}$ It is predominantly in the exegetical and practical sections of the TPT that one finds Mastricht actually using the works of Calvin. The references are largely restricted to Calvin's Scripture commentaries, although Mastricht (1699) does also refer to Calvin's Institutes of Christian Religion twice, ${ }^{15}$ and to Psychopannychia once. ${ }^{16}$ It should be noted, however,

$8.5 e$ the most recent overviews of the life and work of Mastricht in Van Tellingen (2003) and Neele (2009).

9.For example Mastricht (1699:2.2-7, 10 [2x], 11 [2x], 12-3, 14-6 [3x], 20 [2x], 23).

10.In particular as found in the Theologia pacifica of Christopher Wittichius (1671).

11.For example, Mastricht (1699) 1.1 .49 (p.15); 1.2 .72 (p. 44); 1.1 .2 (p. 51); 1.1 .12 (p. 52); 1.1 .25 (p. 56); 1.1 .55 (p. 64); 2.4 .8 (p. 87); 2.8 .3 (p. 112); 2.10 .8 (p. 123); .12.23 (p. 141); 4.30 .34 (p. 371$) ; 5.3 .29$ (p. 430$) ; 5.3 .34$ (p. 432 ); 5.3 .35 (p. 448 ); 5.15.22 (p. 584); 6.2 .6 (p. 649); 6.15 .2 (p. 692); 6.15 .25 (p. 697); 6.8 .27 (p. 745).

12.Mastricht (1699): exegetical, 5.1 .2 (p. 391) (2x); 5.8 .1 (p. 476), doctrinal, 1.1.1 (p. 3); 2.24.3 (p. 237); 8.3.30 (pp. 1058-1076) (3x); elenctic, 1.2.33 (p. 31); 1.4 .16 (p. 90); 1.26 .9 (p. 259); 2.16 .25 (p. 174); 5.12 .22 (p. 545); 3.9 .18 (p. 374); 3.12 .31 (p. 325$) ; 7.1 .27$ (p. 775); 7.1 .34 (p. 777); practical, 3.9 .21 (p. 376); 2.2 .25 (p. 73); 5.8 .20 (p. 483)

13.For example, Mastricht (1699) 7.1.26 (p. 774): 'Quaeritur sextò, an Reformato Ecclesia,_ortum suum repetat à Zuinglio, Luthero, Calvino \&c?'

14.Concerning the elenctical sections, Mastricht (1699:767-785) makes use of Calvin in his discussion on ecclesiology.

15.Mastricht (1699) 3.9.21 (p. 376); 5.20 .22 (p. 545).

16.Mastricht (1699) 3.9.8 (p. 374). 
that where Mastricht in his exegesis comments on and uses Calvin, the Genevan's name occurs together with those of David Pareus (1548-1622) and Andreas Rivetus (1572-1651) - expositors he does not mention in his recommendation of Scripture commentators. ${ }^{17}$ In summary, the actual use of Calvin's work by Mastricht is limited: out of the 25 references and citations, he explicitly draws on Calvin's commentary on Psalm 115, the Epistle to the Galatians 3:13, and the Harmony of the Gospels. Two comments are in order here. Firstly, Mastricht's reference to the Harmony of the Gospels is found together with the two references to the Institutes, leaving the strong impression that Mastricht read Calvin's Scripture commentary and his seminal work on Protestant theology concurrently..$^{18}$ Secondly, the commentary on Psalm 115 is the only work of Calvin which is cited verbatim, ${ }^{19}$ and is found within the context of Mastricht's discussion of the doctrine of God. It is in this context that Mastricht makes extensive use of the book of the Psalms, which is foundational to his doctrinal and practical exposition of the divine attributes as well the Trinity.

\section{Mastricht and Calvin on the Psalms}

With these limitations arising from our survey - that of Mastricht's restricted use of Calvin's work, limited to the Psalms commentary, as well as Mastricht's exegetical insights into the book of Psalms as found in his discussion of theology proper - I turn to a comparative analysis of several texts from the book of Psalms. Although Calvin's commentary on Scripture may seem to differ in genre from Mastricht's systematic theology, it must be noted here that the latter was in fact written for students for the ministry and 'to be used for preaching ${ }^{\prime}{ }^{20}$ whereas the former similarly emerged primarily from Calvin's lectures at the Geneva Academy, founded in part for the training of students for the ministry, and was used for his preaching and discussion with preachers at the congregations (Selderhuis 2000). Furthermore, the loci of the Reformed orthodox systema 'arose directly out of meditation on specific texts and issues of Scripture' (Muller 2007:31-32) as distinctly and uniquely is present in the TPT with its fourfold approach to the theological loci.

Mastricht's use of the book of Psalms in the TPT, then, is primarily found in Book Two, entitled de Fide in Deum

17.Mastricht (1699) 5.1 .2 (p. 391): "per semen illud plhquntiaws collectivè intelligunt Christum cum omnibus suis electis, sic Calvinus, Rivetus, Pareus qui in suo Calvino orthodox ...'; see also 5.8 .1 (p. 476).

18.Mastricht (1699) 5.20.22 (p. 545): 'Quibus nemo felicius ora obturaverit, quam ipse Calvinus Instit. lib. II. c. 16. §. 12. \& in Harmon.

19. Mastricht cites here Calvin's remarkable account of atheism. Mastricht (1699:73), 'Imprimis memorandum habet Calvinus exemplum, Comment. in Psal. CXV. 16. Accidit, inquit, nobis coenantibus, in quodam diversorio, ut profanus De contemptor, sermones nostros, de spe coelestis vitae, deridens, subinde ludibrium hoc evomeret: coelum coeli Domino, terram autem dedit filiis hominum: illic, repente correptus torminibus, ceperit vociferari, O DEUS! O DEUS! atque, ut era patulo gutture; sic boatu suo replebat totum coenaculum. Ego, qui in eum severe excandueram, perrexi meo more, stomachose denuncians, ut tum saltem sentiret, non impune Deo illudi; unus è convivis, homo probus \& religiosus, sed tamen facetus, tune ait, Deum invocas, an Philosophiae tuae oblitus es? cur non in suo coelo, Deum sinis quiescere?

20.Mastricht (1699) 'præfatio': 'Tandem, ut \& usum nostrorum, in homileticis pro concione habeas, id unum moneo, ut cautè observes, praedominans argumentum textus tui; tum nostra, per sua capita conferas, ea quae in rem tuam erunt commodissima, arrectis tantum animi viribus, ut Scripturae locorum vim \& efficaciam, cùm ad amplificandum; tùm ad demonstrandum, assequaris quantum efficacian
satis'. triunum, which deals with the doctrine of God. Here Mastricht examines psalms 2, 16, 90, 115, 119, 139 and 145 , and expounds on and lays a scriptural foundation for, respectively, the doctrines of God the Son, the divine beatitude, eternity, will and affection, righteousness, immensity and omnipresence, and God's infinity and power. Reading Calvin and Mastricht's interpretation of these biblical texts, one observes a contrast and continuity in method and meaning between their exegetical expositions, in part or in whole. A succinct review of several of these expositions illustrates this observation.

Mastricht finds in the second clause of Psalms 16:11, 'Satietas gaudiorum est cum facie tua', the biblical foundation for the divine beatitude or blessedness. He begins by noting that most commentators understand these words as the blessedness of men before God and in the sight of his countenance ${ }^{21}$ - precisely the main thrust of Calvin's exposition, where he comments that the countenance of God, may be understood either of our being beheld by him, or of our beholding him; but I consider both these ideas as included, for his fatherly favor' (Calvin 1989). Mastricht, however, argues that such blessedness is founded on and depends on the divine beatitude, providing exegetical grounds that come from his primarily etymological and grammatical exposition of the text. He observes that the Hebrew words 'fullness of joy' refer to a fullness of divine happiness, delight, perfection and glory..$^{22}$ In him, that is, in the divine essence, is complete blessedness and, therefore, Mastricht asserts, he is the fountain of all blessedness communicated to his own. ${ }^{23}$ As such, Mastricht does not differ that much from Calvin, who comments that God's fatherly favour, his blessedness, precedes our blessedness, 'and is the first cause of it'. He continues: 'By this clause David also intended distinctly to express to whom those pleasures belong, of which God has in his hand a full and an overflowing abundance' (Calvin 1989, 4:233). One observes, however, that in the exposition Mastricht moves immediately from the text's words to the divine beatitude, the source of all blessedness, while Calvin makes an opposite move, that is, from the benefit to the benefactor of blessedness, and observes that the psalmist 'testifies that true and solid joy in which the minds of men may rest will never be found anywhere else but in God'. Though their expositions differ in exegetical approach, in which Mastricht carefully delineates the text, their understanding of the meaning of the biblical text appears strongly to concur.

21.Mastricht (1699) 2.23.2 (p. 231): "Nolim diffiteri, iuxta plerosque interpretes, verba haec capi posse, de beatitudine creaturarum, quâ fruuntur coram facie, \& ex conspectu faciei divinae'.

22.Mastricht (1699) 2.23 .2 (p. 231): 'Beatitudo quae tribuitur: twjmv obwc satietas gaudiorum: ubi obwc copiam notat, plenitudinem, imo \& satietatem: quod beatitudo, non uno aliquo bono; sed confluxu omnium perficiatur. Unde etiam twjmv in plurali adiicitur: qua voce \& bona illa designantur, quae beatum faciunt; \& acquiescentia ac gaudium, expossessione \& fruitione, bonorum istorum oriundum. Utroque significatur, tantam esse in Deo perfectionis \& gloriae, copiam, ex to Utroque significatur, tantam esse in Deo perfectionis \& gloriae, copiam, ex to tantisque attributis oriundam, ut satis habeat, quasi plenus sit, abundet, non tantum ad necessitatem; sed etiam ad laetitiam. Sic ut plus habere non possit, nec
habere desideret'.

23.Mastricht (1699) 2.23 .2 (p. 231): 'Beatitudinis communicatae, $P n^{\prime} m^{\prime} b$ twmson, amaenitates in dextrâ tuâa. Hîc rursus non diffiteor, verba posse usurpari de beatitudine Dei: sed tamen etiam de beatitudine creaturarum participatấ. 
Such nuanced, non-essential differences in the meaning of the text are also found in their exegesis of Psalms 90:1-2 and 145:3. Concerning the former, for Mastricht the words 'of Moses' in the text provide a biblical basis primarily for the doctrine of divine eternity. Calvin's exegesis of these verses points to a dual understanding. He writes: 'Thus the everlastingness of which Moses speaks, is to be referred not only to the essence of God, but also to his providence' (Calvin 1989, 5:462). Mastricht argues that the divine infinite duration is identified in the text in three comparative steps: first, God existed before the mountains were brought forth; second, before the earth was formed - and here Mastricht points out grammatically that the Hebrew word, wat-tohōo-w-lêl (תחולל), can be in the piel or pual form, meaning an activity in a passive sense, such that the earth was formed by divine action; and, thirdly, before the formation of the world, in particular the beginning of time, meaning that only eternity preceded the creation of the world. ${ }^{24}$ Thus, whereas both do acknowledge the divine eternity, it is Calvin who places it in the light of God's providence - and with an emphasis on the temporal - while Mastricht stresses the eternal, establishing the eternity of God in the biblical text primarily on a linguistic basis.

In regard to the exposition of Psalms 145:3, both understand this text to reveal the infinite and immense power of God. Mastricht, however, focuses heavily on the Hebrew text and on grammatical analysis, ${ }^{25}$ whereas Calvin asserts - with a practical dimension - that the text should 'stir up and urge all ... offering to God the praises due to his name' (Calvin 1989; 145, 1-3; CO 32:413), 6:272). Such should be done to his glory continuously, Calvin argues, because of 'the greatness of God as immeasurable ... with admiration of the immensity of his power'.

These examples, then, attest to the fact that Mastricht varies in exegetical method of the biblical text but does not differ in meaning all that much from Calvin's understanding of these texts from the book of Psalms. For both the identification of doctrine arises from the biblical text, although Mastricht demonstrates in his text reflection more concern for the exegetical method; for the grammatical and etymological aspects of the text, while the Genevan interpreter directs the reader in his exegesis to a practical application, to the glory of God.

Such exegetical continuity of meaning of the biblical text between Calvin and Mastricht is less prevalent in the following commentary on Psalms 139:7-10 and 2:7-8. Calvin comments on Psalms 139:7-12 as one textual unit, and comments on verses 7-10 together. He notes:

They misapply the passage who adduce it as a proof of the immensity of God's essence; for though it be an undoubted

24.Mastricht (1699) 2.11.2 (p. 128): 'Vox Il wjt capi potest, vel active in Pihel, sicut Prov xxv. 23. Deut. xxxll. 18. ut notet, antequam peperisses; vel passive, in Puhal Psal. li. 7. Prov. viii. 24. 25.'

25.Mastricht (1699) 2.9 .2 (p. 117): 'Textus habet elogium, seu celebrationem quandam Dei, cuius argumentum est, infinita eius magnitudo. [...] Magnus dicitur Iwdg Refertur, vel ad quantitatem, vel ad qualitatem [...] quod infinitus sit: vel magnitudinem [...]. Scil. à magnitudine omnia excedente, seu infinitâ [...]. E magnitudinis eius, non est investigatio : rqj Wwia'. truth that the glory of the Lord fills heaven and earth, this was not at present in the view of the psalmist. (Calvin 1989; 139, 7-10) (CO 32:379, 6:211)

Mastricht, who for the most part follows the same grammatical-analytical textual division as Calvin, focuses here in Psalm 139 on verses 7 to 10, and writes: 'the divine immensity and omnipresence are strongly represented in the words of the text, of which the psalmist gives proof. ${ }^{26}$ Thus, whereas for Calvin the psalmist did not have divine immensity in view, Mastricht emphasises that the psalmist provides evidence of this divine attribute - a difference in meaning of the text. Calvin's exposition also focuses on the thrust of these verses; that is, it speaks of divine 'knowledge or inspection' (Calvin 1989:139, 7-10; CO 32:379, 6:211). He comments, 'David means in short that he could not change from one place to another without God seeing him, and following him with his eyes as he moved' (Calvin 1989:139, 7-10; CO 32:379, 6:211). We can infer from this that Calvin alludes to the divine omniscience - an expression he does not use but does describe: 'God's eye penetrates heaven and hell, so that, hide in what obscure corner of the world he might, he [the psalmist] must be discovered by him.' (Calvin 1989:139, 7-10; CO 32:379, 6:211). Mastricht, on the other hand, delineates the clauses into two major parts, where he first observes a double question, and secondly an indication of omnipresence as related to immensity. Concerning the former, Mastricht disregards the understanding that the clause 'Where shall I go from your Spirit?' refers to the third person of the Trinity ${ }^{27}$ - a thought that is not mentioned by Calvin, but can be deduced when he writes on the same clause that ' $[b]$ y the Spirit of God we are not here, as in several other parts of Scripture, to conceive of his power merely, but his understanding and knowledge' (Calvin 1989:139, 7-10; CO 32:379, 6:211) Moreover, for Calvin, such divine knowledge is manifested wherever the psalmist goes, and in particular because of the divine power.

Mastricht follows the same line of argument in his answer to the second question of the text, 'where shall I flee from your presence?' He replies, 'Nowhere' - because of God's knowledge as well as his 'power, work, and essence'. ${ }^{28}$ However, Mastricht, in contrast to Calvin, continues to expound on the text by noting that the subsequent clauses provide additional explanations not only of the divine omnipresence but also of his immensity. ${ }^{29}$ According to Mastricht, the psalmist affirms that wherever he goes, from the highest heavens to the depths of the earth - an infinite distance - or wherever he is present, even in the middle of the earth or in the 'uttermost parts of the sea', God is there, not only in his essence or by his knowledge but also,

26.Mastricht (1699) 2.10.2 (p. 121): 'Istam Dei immensitatem \& omnipraesentiam, graphicè repraesentant verba textus praefixi.

27.Mastricht (1699) 2.10.2 (p. 121): 'Per Spiritum tuum, nonnulli personam quandam, a Patre diversam, seu Spiritum S. intellectum volunt... sed nescio, an satis solide; tutius igitur, Deus theologice consideratus, ut fit loh. IV. $24^{\prime}$.

28.Mastricht (1699) 2.10 .2 (p. 122): 'non de cognitione Dei tantum; aut de virtute \& operatione tantum: sed etiam, de ipsâ eius essentiâ'.

29.Mastricht (1699) 2.10 .2 (p. 122): 'Declaret \& probet merismw seu distributione terminorum, omnipraesentis huius immensitatis, pro triplici distantiae differentia .... 
Mastricht explicitly argues, in his providence. Therefore, as a summary he writes: 'God is immense and omnipresence, with his essence and knowledge, with his works coexist in all space and all creatures in space. ${ }^{30}$ In other words, Mastricht argues for a divine presence everywhere per essentia. Calvin's exposition of this biblical passage, on the other hand, is directed implicitly to the divine omnipresence, and he reminds the reader with a practical application (Calvin 1989:139:7-10; CO 32:379, 6:211) Mastricht restricts his reading of this passage to exegetical comments in which practical implications, as found in Calvin's interpretation, are absent. Moreover, Calvin's attention to the divine omniscience, which is everywhere present, is continued but extended by Mastricht in the dual focus he sees in the biblical text, namely, on divine immensity and omnipresence.

The question arises, then, what constitutes this difference of biblical interpretation? This enquiry applies specifically to the divergent understanding of Calvin and Mastricht of Psalm 2:7-8. Before attempting to answer this question, I turn to Calvin and Mastricht's exegetical comments on the words of Psalm 2:

I will declare the decree: The Lord had said unto me, you are my son; this day have I begotten you. Ask of me, and I will give you the heathen for your inheritance, and the uttermost parts of the earth for your possession.

Calvin begins by commenting that David, as son of God, 'publishes a decree', or a proof, of his rightful ascension to the throne commanded by God. But, Calvin continues:

this was more truly fulfilled in Christ, and doubtless, David, under the influence of the spirit of prophecy, had a special reference to him ... [and] represented the person of Christ.' (Calvin 1989:2, 7; CO 31: 46, 4:16)

Calvin points out that David was begotten by God, and therefore the words 'I have begotten you' ought to be understood as 'referring to men's understanding or knowledge of it', denoting the time of his enthronement. Though the Geneva interpreter does not deny that these words may apply to Christ as only begotten son of the Father, he notes:

This passage, I am aware, has been explained by many as referring to the eternal generation of Christ; and from the words 'this day', they have reasoned ingeniously as if they denoted an eternal act without any relation to time.

Finally, he asserts that the day of Christ, as the Son of God, is manifested by his coming into the world as well, and in particular on the day of his resurrection. In the subsequent verse, Calvin expounds on the text Christologically, pointing to the mediatorial work of the Son - not only in his kingly authority over the whole world, but in particular in his redemptive work. Calvin writes:

30.Mastricht (1699) 2.10 .2 (p. 121): "[Q]uibus argumentum, Psaltes praestiturus, providentiae divinae; Dei immensitatem, velut per partes ac terminos, delineat.' Mastricht (1699) iii (p.122): 'Hinc igitur, nil clarius pellucet, quam quod Deus Mastricht (1699) iii (p.122): 'Hinc igitur, nil clarius pellucet, quam quod Deus
immensus \& omnipraesens sit, essentiâ pariter \& cognitione, iuxta ac operatione; coëxistens omni spacio, \& omni creaturae in spacio.
Christ collects the dispersed remnants of his people from all quarters, and in the midst of this wretched desolation, keeps them joined together by the sacred bond of faith (Calvin 1989:2, 7; CO 31:48, 4:19).

This succinct notion of Christ as mediator in Calvin's exposition becomes a central and much-expanded notion in Mastricht's exposition of Psalm 2:7-8.

According to Mastricht, this text declares (1) the divine household or pact (economicum officium), (2) the Second Person of the Trinity, and (3) his office. ${ }^{31}$ For Mastricht, the (grammatical) analysis of this biblical text then includes a theological notion the covenant of the divine economy, and the Son as 'economicus' (Persona Filii ceu oeconomi). The second person of the Trinity is discussed from the perspective of the speaker and of what is said. The latter then includes a discussion on the sonship, the generation and the inheritage. In addition, the exposition of the generation of the Son is worked out in meticulous detail, as Mastricht discusses who generates; the time of generation, the act of generation; and the generated one, David, a type of Christ. ${ }^{32}$ As such, Mastricht takes the entire Hebrew text and breaks it down into individual (identifiable) parts. He then expounds on each part individually and brings it all together in closing. To show the depth of his argument, we will examine Mastricht's treatment of the first part of the biblical text dealing with the Son and the covenant. ${ }^{33}$ The text (Ps 2:7) begins, according to Mastricht, with the covenant between the Father and the Son, where the Son is introduced in a speaking manner such as 'one finds in the 6th verse, the Song of Solomon and other poetry' ${ }^{34}$ These words can accordingly be understood as a typus, the confirmation of the kingdom to David, and an antitypus, the proclamation of the eternal covenant to Christ. Mastricht assures the reader that the biblical text really speaks of a covenant. He argues that the Hebrew word (hōq) (חק) constitutes a concilium pacis, or council of peace. ${ }^{35}$ That it is a divine covenant is based on the word 'la' (א), which is used instead of 'ta' (את). Mastricht notes some of the possible readings. 'Whatever reading one follows,' Mastricht writes, the text indicates the covenant between the Father and the Son (Is 53:10, or Zch 6:10, the council of peace, concilium pacis) by which the Father says, 'You are my Son.' The Christological and covenantal interpretation is obvious. Calvin does attest the former, although he gives a stronger

31.Mastricht (1699) 2.26.2 (p. 251): "Proinde ... Filium contemplabimur qui sui proswoigraqian \& officium œeconomicum, ex pacto œeconomico refert, verbis præfixis, ex Psalmo 2:7-8.' The following paragraph follows the argument in Neele præfixis, ex Psalmo
(2009:255-258).

32.Mastricht (1699) 2.26 .2 (pp. 251-252): '1. Fœdus œconomicum, inter se \& Patrem Narrabo ipsum decretum ... 2. Persona Filii, ceu œeconomi: Filius meus tu ... a. dicens Jehova ... b. Dictum: Filius meus tu es ... 1. Filiatio hta inb 2. Generatio æterna Pitili Mwih 'na, a. generans ... na, b. generandi tempus ... Mwih, c. generandi actus ... Pitili, d. genitus ... 3. Hæreditas a. Stipulatio Patris œconomica b. Promissio reciproca ....'

33. Mastricht (1699) expounds on the remainder of the biblical text in depth, but we will summarise only his exegetical results.

34.Mastricht (1699) 2.26 .2 (p. 251): '1. Fœdus œeconomicum Ex abrupto introducitur persona secunda loquens, nempe idem Rex, de quo vers. 6 quales sermonum alternationes, non raræ sunt, in Cantico, aliisque scriptis Poëticis.' This sentence is found verbatim in Poole's commentary, with the reference 'Gej[erus]'. See Poole (1669-1676).

35. Mastricht (1699): 'qh statutum notat, quod constitutum sit, in æterno consilio Pacis, inter Patrem \& se.' 
Davidic interpretation than Mastricht does. Furthermore, for Mastricht the speaker in the text is Yah-weh and should be taken here as a personal and household name of the Father, as 'is confirmed in the text'. ${ }^{36}$ The question then arises, 'When, did he say?' According to Mastricht, some answer by pointing to Christ's baptism (Mt 3:17) or to the time of the transfiguration (Mt 17:5). However, Mastricht argues that the biblical text points to an eternal stability. Thus, from eternity to eternity is the divine 'now' ${ }^{37}$ The saying, Mastricht notes, speaks of the Second Person, as the word relates grammatically to the sonship. Accordingly, one should not follow the vocative reading of Grotius's antiTrinitarian hypothesis, 'O! my son.' ${ }^{38} \mathrm{No}$, Mastricht argues, it should be read emphatically:

My son you are! ..., [that is], not by creation, as Adam (Lk 3:38) or angels (Job 38:7), and not by adoption, which belongs to the believers (Jn 1:12; 1 Jn 3:1), but by nature and generation. Mastricht (1699) 2.26.2.2.B.1 (p. 251)

Thus, the second person, generated by the Father, is divine.

Mastricht also counters the Socinians by stating that the one generated ('you') is not ultimately David. He notes that others interpret this 'you' as David, an example of Christ, or as Solomon (2 Sm. 7:14). However, he comments that most interpret the text as speaking about the Messiah as attested to in the New Testament (Acts 13:33; Heb 1:5), and that the Son is not spoken of as adopted but as his own (proprio) Son (Rm 8:32; Jn 1:4; 3:16). Mastricht concludes, then, by affirming the divinity of the Son and the personal distinction between the Father and the Son. ${ }^{39}$

In the second part of the text, Mastricht concentrates on the heritage of 'the nations', that speaks here of a promise in which is made known the lordship of the Mediator resulting from his redemptive work. ${ }^{40}$

In summary, where Calvin is succinct in his exposition of Psalm 2:7, indicating that the 'decree' points primarily to David as a type of Christ, and to his proof of kingship, Mastricht elaborates extensively on the etymological meaning, establishing the theological interpretation of the decree as a covenant between the Father and the Son - a notion that is absent in Calvin's interpretation. Furthermore, Mastricht's comprehensive explanation of 'begetting', pointing to the eternal generation of the Son, thereby rejecting Grotius's interpretation and the Socinian antiTrinitarian inclination, is dismissed by Calvin - although Calvin does acknowledge the possibility of such a reading.

36. Mastricht (1699): 'a. Dicens Jehova ... hic personaliter \& ceconomice capitur, pro Patre, sicut passim Ps. 33:6.'

37.Mastricht (1699): 'Dixit, quando? ... cum ratione decreti, ante omne tempus; ratione exsecutionis in tempore, dixerit, dictat \& dicturus sit.'

38.Mastricht (1699) 2.26.2.2.B.1 (p. 251): 'Filiatio hta inb, Filius meus tu, supple es hta hîc non est pro Vocativo: O Fili mi, ut Grotius, suis hypothesibus antitrinitariis serviens, volebat.'

39.Mastricht (1699) 2.26 .2 (p. 251): 'Ex quo patet, tum Filii deitas; tum distinctio personalis inter Patrem \& Filium.'

40.Mastricht (1699) 2.26 .2 (p. 252): 'Denotatur dominium Mediatorium, ei, ex redemptione.'
Finally, even though both commentators point to Christ as mediator in Psalm 2:8, it is Calvin - and not Mastricht - who includes a practical observation in his exegetical reflection on the text.

\section{Conclusion}

In conclusion, the reception of Calvin's work in Mastricht's magnum opus of theology is noteworthy exegetically, both at times differing about the doctrinal meaning of the biblical text. That is to say, on the one hand, that Calvin's interpretation reflects the interweaving of (limited) grammatical-analytical exegetical reflections together with doctrinal and practical comments. Mastricht, on the other hand, shows in his exegesis an almost exclusive focus on the analysis of the text, and diverts the doctrinal and practical inferences to a separate discussion - though not separated from the biblical text and its exegesis. For example, Calvin's practical comment on Psalm 145, directing the reader to the glory of God and considering the divine immense power, is shared by Mastricht - though not in the exegetical section, but rather in the practical section of his discussion of the divine infinity and magnitude. Here he writes, 'the divine greatness is reason for us to glorify and praise God immensely, ${ }^{\prime 41}$ and provides in a much-expanded passage practical usus for the believer arising from the biblical text. Furthermore, and concerning the exegetical method, Mastricht shows more concern for the Hebrew in the text analysis than what one can find in Calvin's commentary on this text - the consistent and similar division of the clauses of the examined texts excepted. That Mastricht gives more attention to the etymological and philological issues may arise from his extensive Hebrew knowledge and deep acquaintance with the rabbinical commentaries, attested to during his Hebrew and Old Testament professorship from 1667-1677 at the universities of Frankfort an der Oder and Duisburg, as well as following the intensification of Renaissance humanist concern for the original language in Mastricht's time.

These factors may contribute, therefore, to the concluding observation that Mastricht in some cases stands in overall exegetical continuity, in method and meaning, with Calvin - albeit with discernment on Mastricht's part, given that he places doctrinal, polemic and practical reflections arising from the biblical text in distinct sections. However, such factors do not account for major differences as noted in the exegesis of Psalm 139 and, in particular, of Psalm 2. In regard to the former, Calvin clearly rejects the doctrine of the divine immensity, which Mastricht affirms, though both do confirm that the doctrine of omnipresence arises from the text. Is it that Mastricht takes into account the Socinian reading of this psalm by making a distinction between the mode of the divine presence in heaven and the mode of his presence in the grave? Is it against the Socinian understanding that the divine omnipresence results from his power and not from the divine essence? Or is Mastricht concerned with the 41.Mastricht (1699) 2.9.11 (p. 120): 'infinita Dei magnitudo, argumentum_nobis suppeditat, quò, infinitis laudibus.' 
Cartesian understanding that 'the divine omnipresence was merely a matter of external operation of power ... failing to distinguish between circumscriptive, definitive and repletive presence'? (Mastricht 1699:124, 2.10.10; Muller 2003:341). Although Mastricht addresses and rejects these Socinian and Cartesian ideas distinctively in the elenctic section belonging to his discussion of the divine immensity and omnipresence, this does not provide an answer as to why Calvin rejects and Mastricht includes the doctrine of immensity as an option in the exegesis. Mastricht notes that the texts implicitly state that the One who is present on high and below, as well as in the midst of the world, is concurrently immense and omnipresent. The proposition of everywhere presentness by inductive reason presupposes and assumes, for Mastricht, immensity. ${ }^{42}$ This, then, may provide some direction for Mastricht's approach to the biblical text, and as such lays the groundwork for his refutation of the Socinian and Cartesian position. Although his exegetical work forms the basis of his doctrinal, elenctical, and practical reflection of a theological locus, it was shaped by contemporary debates. This may also serve in part as an explanation of the exegetical differences between Calvin and Mastricht on Psalm 2:7-8. Although Calvin and Mastricht share essentially the same Christological interpretation of this psalm - in particular, that of Christ as mediator - it is Mastricht who significantly expands on this thought and explicates the importance of the concept of covenant. This concept is absent from Calvin's exegetical reflection, as is the doctrine of the eternal generation of the Son - a thought familiar to but not shared by Calvin. On this point, Mastricht addresses Grotius's deviant reading of the text, shared by the Socinians, not in the elenctical but in the exegetical section of the locus De Deo Filio.

Mastricht is clear in his guidelines for biblical interpretation: doctrinal differences are not drawn out of the biblical text, unless variant readings give reason for doing so. On the basis of these guidelines he refutes Grotius's anti-Trinitarian hypotheses. In addition to refuting exegetical options on account of their theological implications, Mastricht also expands his exegetical insights, providing a more comprehensive foundation for his theological thought - such as, in Psalm 2, the concept of the covenant. Here the question arises whether the development of covenant theology in the late-sixteenth and seventeenth centuries or, in particular, the Voetian-Cocceian debate on the understanding of the covenant, influenced Mastricht's interpretation of this psalm. Such a possibility may not be excluded entirely, though it must be mentioned that he does not impose the concept of the covenant on the text. On the contrary, he again shows concern for the Hebrew text and consults the Masoretic and Septuagint readings, as well as the Arabic and Ethiopian renderings of the text, and even includes the Targum commentary when formulating his understanding of the Hebrew word hōq (חק) as 'statue, decree, and covenant economy'. Calvin speaks in this regard only of a 'mutual love which exists between the Father and the Son'. Although propositionis, assumptionem confirmat Inductione ....' there is a notable difference in the exegetical results between Calvin and Mastricht as found in Psalm 2:7-8, Mastricht's interpretation may be formed in part due to theological controversies, but at the same time strengthens the Christological importance of this biblical text - an emphasis that is shared by Calvin as well, but is expounded on further by Mastricht not in the exegetical section, but rather in the doctrinal, elenctical and practical sections.

This brings us to the second concluding remark: Mastricht's exegesis cannot be evaluated without a reading of his doctrinal, elenctical and practical reflections on the theological subject in which consists the interconnectedness of his fourfold approach arising from the text of Scripture - a parallel approach but one that is integrally present in Calvin's commentary on Scripture. The approach suggested here to Mastricht's understanding of the biblical text may contribute to a more comprehensive understanding of the reception - or, more precisely, the appropriation - of Calvin by Mastricht than presented so far, a suggestion further supported by Mastricht's parallel reading of Calvin's Institutes and commentaries which has already been noted.

In summary, if Post-Reformation 'systematic theology [was] so closely wedded to the textual and linguistic work of the exegete', then the historical-theological context of the era has to be taken into consideration to note the exegetical continuity and 'discontinuity between Calvin and Post-Reformation Reformed Orthodoxy in the meaning of the biblical text, as shown in the case of Mastricht's TPT - because both doctrine and praxis arose out of the text of Scripture.

\section{Acknowledgements}

The author is grateful for the valuable editorial suggestions offered by Andreas Beck, Evangelische Theologische Faculteit, Leuven, Albert Gootjes, Calvin Theological Seminary, and Kenneth P. Minkema, Yale University.

\section{Competing interests}

The author declares that he has no financial or personal relationship(s) that may have inappropriately influenced him in writing this article.

\section{References}

Berkhof, L., 1950, Principles of biblical interpretation, Baker Books, Grand Rapids.

Berthoud, P., 2010, 'Jean Calvin, interprète des psaumes messianiques', Théologie Évangélique 9(2), 105-22.

Bray, G., 1996, Biblical interpretation past \& present, Intervarsity Press, Downers Grove.

Burmannus, F., 1671, Synopsis theologiæ \& speciatim oeconomiæ foederum dei, Cornelius Jacobi Noenardus, Utrecht.

Calvin, J., 1863-1900, 'Opera quae Supersunt Omnia', in G. Baum, E. Cunitz \& E. Reuss (eds.), Corpus Reformatorum, Schwetschke, Braunschweig.

Calvin, J., 1989, lib. Psalmorum comm, transl. J. King, 22 vols, Baker Bookhouse, Grand Rapids.

Cloppenburg, J., 1684, Theologica opera omnia, Gerardus Borstius, Amsterdam.

Cobb, D., 2010, 'L'exégèse de Jean Calvin, actualité et spiritualité', La Revue Réformée $61(5), 21-36$.

Coccejus, J., 1665, Summa theologiae ex scripturis repetita ...Sumptibus Samuelis Chouët, Geneva. 
Cocceius, J., 1701, Opera Omnia theologica, P\&J Blaev, Amsterdam.

d'Assonville, V.E., 2009, 'Exegesis and doctrina', in H.J. Selderhuis (ed.), The Calvin handbook, pp. 378-384, Eerdmans, Grand Rapids.

d'Assonville, V.E., 2010, 'Calvin as an exegete of scripture: A few remarks with reference to Calvin research in general', in J. Calvin, 1509-2009: A South African perspective"', In die Skriflig 44(S3), Gerber supplement, S129-S143.

Engammare, M., 2012, 'Jean Calvin exégète humaniste', in B. Boudou \& A-N. PoueyMounou (eds.), Calvin et l'humanisme: Actes du symposium d'Amiens et Lille III (25-26 novembre 2009), pp. 53-72, Droz, Geneva.

Graafland, C., 1993, 'Schriftleer en schriftverstaan in de nadere reformatie', in T. Brienen, K. Exalto, C. Graafland, B. Loonstra, W. van 't Spijker (eds.), Theologische aspecten van de Nadere Reformatie, p. 35, Boekencentrum, Zoetermeer.

Greijdanus, S., 1946, Schrifbeginselen ter Schrifverklaring en Historisch overzicht over theorieën en wijzen van Schriftuitleggingen, Kok, Kampen.

Handy, L.K., 2009, 'Luther and Calvin read Psalm 29', in L.K. Handy (ed.), Psalm 29 through time and tradition, pp. 79-89, Pickwick, Eugene.

Heidanus, A., 1686, Corpus theologiæ christianæ in quindecim locos, Johannes de Vivie \& Jordanus Luchtmans, Leiden.

Heidegger, J.H., 1700, Corpus theologiæ christianæ, David Gessner, Zürich.

H. Henry Meeter Center, n.d., The John Calvin bibliography, viewed 04 January 2014, from http://www.calvin.edu/meeter/publications/calvin-bibliography.htm

Holdt, M., 2010, 'John Calvin and Psalm 110: The Psalm for yesterday and todayPsalm 110', in D.W. Hall (ed.), Preaching like Calvin: Sermons from the 500th anniversary celebration, pp. 215-24, P\&R Publishing, Phillipsburg.

Hoornbeek, J., 1689, Theologiae practicae partes duae, Iohannem \& Guilielmum van de Water, Utrecht.

Huisman, F.W., 2001, Bibliografie van het gereformeerd Piëtisme in Nederland to 1800, Uitgeverij Op Hoope, Woudenberg.

Muller, R.A., 2003, Post-reformation reformed dogmatics, 4 vols., 2nd edn., Baker Academic, Grand Rapids.
Muller, R.A., 2007, 'Biblical interpretation in the sixteenth and seventeenth centuries', in D.J. McKim (ed.), Dictionary of major biblical interpreters, IVP Academic Downers Grove, p. 31.

Muller, R.A., 2009, 'A tale of two wills? Calvin and Amyraut on Ezekiel 18:23', Calvin Theological Journal 44(2), 211-225.

Neele, A.C., 2009, Petrus van Mastricht (1630-1706). Reformed Orthodoxy: Method and Piety, Brill, Leiden/Boston. http://dx.doi.org/10.1163/ ej.9789004169920.i-344

Nicole, E., 2010, 'Calvin interprète de la Genèse', La Revue réformée 61(5), 1-20.

O'Dell Bullock, K., 2002, 'Post-reformation protestant hermeneutics', in B. Corley, S. Lemke \& G. Lovejoy (eds.), Biblical hermeneutics: A comprehensive introduction to interpreting scripture, 2nd edn., p. 129, Broadman \& Holman Publishers, Nashville.

Poole, M., 1669-1676, Synopsis criticorum aliorumque sacrae scripturae interpretum I: Præfatio (III), S. Flesher, London.

Post Reformation Digital Library n.d., Secondary sources, viewed 04 January 2014, from http://www.prdl.org/secondary.php

Selderhuis, H.J., 2000, God in het midden: Calvijns theologie van de Psalmen, Kok, Kampen.

Van Asselt, W., 2011, 'Quid est homo quod memor es ipsius?' Calvin and Cocceius (1603-1669) on Psalm 8', Church History and Religious Culture 91(1/2), 135-147. http://dx.doi.org/10.1163/187124111X557818

Van Mastricht, P., 1666, De optima concionandi methodo paralipomena, Huebneri, Frankfort an der Oder.

Van Mastricht, P., 1699, Theoretico-practica theologia, Thomas Appels, Utrecht.

Van Tellingen, A.E., 2003, 'Het leven en enige aspecten uit de theologie van Petrus van Mastricht 1630-1706', Master's thesis, Faculty of Theology, University of Utrecht.

Wilcox, P., 2011, 'John Calvin's interpretation of lamentations' in R.A. Parry \& H.A. Thomas (eds.), Great is thy faithfulness?: Reading lamentations as sacred scripture, pp. 125-30, Pickwick, Eugene.

Wittichius, C., 1671, Theologica pacifica, Boutesteyn, Leiden. 